軽金属 第 58 巻 第 7 号 (2008), 295-298

$$
\begin{gathered}
\text { セミソリッドスラリーを用いた } \\
\mathrm{AZ} 31 \mathrm{~B} \text { マグネシウム合金薄板の連続鋳造 }
\end{gathered}
$$

$$
\text { 島田 浩和 } * \text { ・城戸 太司* ・茂木 徹一 ** }
$$

Journal of Japan Institute of Light Metals, Vol. 58, No. 7 (2008), pp. 295-298

\title{
Continuous casting of AZ31B magnesium alloy sheet from semisolid slurry
}

\author{
Hirokazu SHIMADA*, Futoshi KIDO* and Tetsuichi MOTEGI**
}

Experiments for casting AZ31B magnesium alloy sheets were performed in a semisolid continuous casting process. The semisolid slurry was produced using an inclined cooling plate, and the sheet was continuously cast by a twin roll caster. The casting sheet width was influenced by the roll speed, amount of semisolid slurry fed into the twin rollers, and the nozzle angle of inclination to the lower roll. The widest sheet was obtained at a $21.5 \mathrm{~m} / \mathrm{min}$ rolling speed, a -5 degree nozzle inclination angle, and $10.2 \times 10^{-3} \mathrm{~m}^{3} / \mathrm{min}$ of slurry. The sheet surface was smooth, and granular grains appeared throughout the sheet.

(Received December 19, 2007 Accepted April 7, 2008)

Keywords: casting, semisolid

\section{1. 緒言}

近年, $\mathrm{CO}_{2}$ ガス排出削減のために, 自動車や航空機をはじ めとした輸送機器は軽量化が求められ, それらの構成材料と して比重の小さいマグネシウム合金が注目されている。マグ ネシウム材料のうち, 現在, 圧延加工で製造される薄板は, まず鋳造によりスラブを作製して，それに熱間や温間圧延を 繰返すという多くの工程を経るために, 薄板材のコスト高の 一因になっている。そのコスト低減をはかるために, 圧延工 程を大幅に省略できる連続鋳造による薄板の製造が試みられ ている ${ }^{1)}$ 。これは扮もに双ロールや単ロールを用いて，溶湯 を直接凝固させる作製方法である。

著者らあすでに傾斜冷却板法により AZ31B マグネシウム合 金を用いて，セミソリッドスラリーを作製して，双ロールに よる連続鋳造を行い, 厚さ $2 \mathrm{~mm}$ および $3 \mathrm{~mm}$, 板幅 $100 \mathrm{~mm}$, 長さ $1 \mathrm{~m}$ の薄板の作製が可能であること, およびその鋳造組 織は微細な初晶が薄板全体に分布していることを報告した ${ }^{2)}$ 。 このようなセミソリッドスラリーを鋳造することは, 完全溶 湯よりも低温鋳造が可能であること，凝固速度が大きいこと などのために, 薄板製造時の制御がしやすいこと, さらに鋳 造組織の初晶が微細粒状化しているために, その後の塑性加 工性の向上が期待できると考えられる。

本研究は, 双ロールを用いたセミソリッドスラリーの連続 鋳造による薄板の作製において, 当実験設備で得られる限度 の板厚 $2 \mathrm{~mm}$, 板幅 $200 \mathrm{~mm}$ の長尺薄板を作製して, より実用 に近い幅広板材の製造の基礎資料を得ることを目的とした。 具体的には, 板幅に及ぼす双ロールへのスラリーの供給量, ロール周速度, およびスラリーがタンディッシュから双ロー
ルに送られるときのタンディッシュの双ロールに対する角度 の影響を調查した。

\section{2. 実験方法}

Fig. 1 は実験に用いた薄板連続鋳造装置の模式図であり， 扣もに溶解用電気炉, 傾斜冷却板, タンディッシュ, 双ロー ルから構成された水平型である。また供試材は市販の AZ31B マグネシウム合金である。これを電気炉内のステンレス鋼る つぼに $8 \mathrm{~kg}$ 装入し, フラックスで空気を遮断して溶解した。 溶湯を所定温度に保持した後, 湯面制御棒を降下させて溶湯 面を上昇させて，るつぼ内に垂直に設置した給湯管を通して 傾斜冷却板上に流下させた。この傾斜冷却板上では初晶が晶

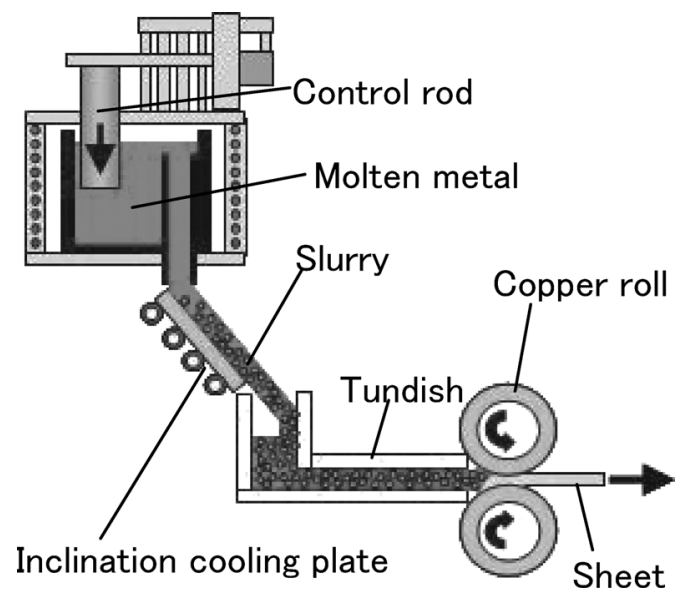

Fig. 1 Schematic illustration of equipment used for continuous casting sheet of semisolid slurry.

\footnotetext{
*千葉工業大学大学院（％ 275-0016 千葉県習志野市津田沼 2-17-1)。Graduate School of Chiba Institute of Technology (2-17-1 Tsudanuma, Narashino-shi, Chiba 275-0016).

***葉工業大学（習志野市)。Chiba Institute of Technology (Narashino-shi, Chiba).
} 
Table 1 Casting conditions for making semisolid slurry

\begin{tabular}{l|c}
\hline \hline Casting temperature, $T /{ }^{\circ} \mathrm{C}$ & 640 \\
\hline Length of inclination cooling plate, $L / \mathrm{mm}$ & 150 \\
\hline Angle of inclination cooling plate, $A /^{\circ}$ & 60 \\
\hline
\end{tabular}

Table 2 Relation between roll speed and amount of semisolid slurry fed into the twin rolls

\begin{tabular}{l|rrrr}
\hline \hline $\begin{array}{l}\text { Roll speed, } \\
\mathrm{s} / \mathrm{m} \cdot \mathrm{min}^{-1}\end{array}$ & 27.5 & 26.0 & 24.5 \\
& & 23.0 & 21.5 & \\
\hline $\begin{array}{l}\text { Amount of semisolid slurry, } \\
l / 10^{-3} \mathrm{~m}^{3} \cdot \mathrm{min}^{-1}\end{array}$ & 4.5 & 5.7 & 6.8 & 7.9 \\
& & 9.0 & 10.2 & \\
\hline
\end{tabular}

出するとと屯に溶湯の流動により遊離し ${ }^{2}$, 下方に置いた夕 ンディッシュに流下して，セミソリッドスラリーとなり，夕 ンディッシュ内溶湯圧により双ロールに供給された。なお, セミソリッドスラリーは傾斜冷却板上への鋳造温度，傾斜冷 却板の長さおよび角度により性状が異なるが, 本研究では, Table 1 に示したように, 前報 ${ }^{3)}$ で示した初晶マグネシウム がもっとも微細粒状晶になる条件を採用した。

\section{1 板幅に及ぼすロール周速度とスラリー供給量の影響}

双ロールは冷却能の大きい内部を水冷した純銅製で構成さ れ, 直径 $300 \mathrm{~mm}$, 幅 $250 \mathrm{~mm}$ である。Table 2 は実験に用い たロール周速度およびスラリー供給量を示したものである。 本研究では板幅を広げるためには, 板厚が双ロールで制御さ れているために，スラリ一供給量を増やすことで排出される 薄板の体積が増えると考えた。そこで，ロール周速度を小さ くして，スラリ一供給量を多くすることにより板幅に及ぼす 影響を調べた。なお夕ンディッシュ底面は下ロールに対して 水平であり，これをタンディシュ角度 $0^{\circ}$ とした。また双ロー ルへのスラリー供給量は湯面制御棒の降下速度で制御した。

\section{2 板幅に及ぼすタンディッシュ角度の影響}

本研究では，マグネシウム合金スラリーの酸化および燃焼 を防止するために，メルトドラッグ法で使用されているク

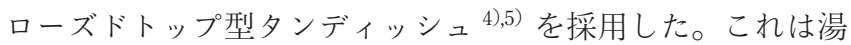
溜り部执よびノズル部の 2 つから構成されているために， ス ラリーがノズルを通過するときに大気との接触を防止するこ とができる利点がある。そこで使用したタンディッシュは,

Fig. 2 に示したような形状および寸法でとくに断熱性の優れ たけい酸カルシウムボードで作製した。本研究ではノズル内 でスラリーが広がることで板幅も広がると考え, タンディッ シュの設置角度を変化させた。Fig. 2 (a) に傾斜冷却板から 流下したスラリーのタンディッシュ内での流れを示す。Fig. 2 （b）は夕ンディッシュのノズル部の上部からのスラリーの広 がりを模式的に示したものである。図のようにノズル内部の 高さが $8 \mathrm{~mm}$ であるため, タンディッシュの湯溜り部にたまっ たスラリーの压力によりノズル内でスラリーが広がると考え た。そこで, 双ロールに対するタンディッシュの角度を Fig. 3 に示したように, 水平のときを $0^{\circ}$ とし， $5^{\circ} ， 10^{\circ}, 15^{\circ}$ およ び $-5^{\circ}$ にした場合の板幅に及ぼす影響を調べた。

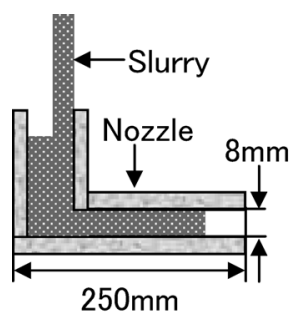

(a)

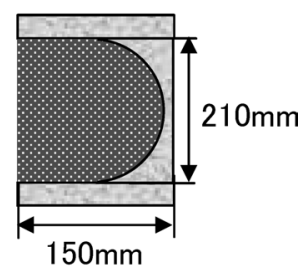

(b)
Fig. 2 Flow of slurry in a tundish. (a) is the tundish (side view), and (b) is the nozzle portion (top view).

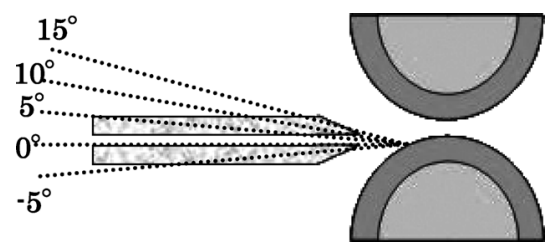

Fig. 3 Nozzle inclination angles to lower roll.

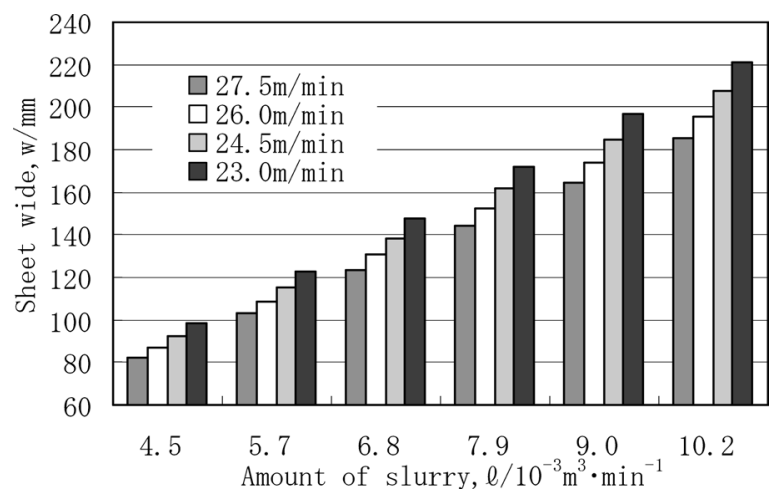

Fig. 4 Influence of amount of semisolid slurry on width of casting sheet calculated by amount of slurry fed into the twin rolls.

\section{3 ロール周速度 $26.0 \mathrm{~m} / \mathrm{min}$ での板幅に及ぼすタン ディッシュ角度およびスラリー供給量の影響}

前節 2.2 で得られた結果を踏まえて，ロール周速度を 26.0 $\mathrm{m} / \mathrm{min}$ に固定し, タンディシュ角度が $5^{\circ}, 10^{\circ}, 15^{\circ}$ のうち, もっとも広幅の薄板が得られた条件を用いて, スラリ一供給 量を増加させて，板幅に及ぼす影響を調べた。

\section{4 設置角度 $-5^{\circ}$ での板幅に及ぼすロール周速度の影響}

2.2 節で得られたタンディッシュ設置角度 $-5^{\circ}$ において, スラリー供給量が少ないと，薄板が鋳造できないことが考え られる。そこでスラリー供給量を $10.2 \times 10^{-3} \mathrm{~m}^{3} / \mathrm{min}$ に固定し て, ロール周速度を $24.5 \mathrm{~m} / \mathrm{min}, 23.0 \mathrm{~m} / \mathrm{min}$ および $21.5 \mathrm{~m} / \mathrm{min}$ と次第に小さくして板幅に及ぼす影響を調査した。

\section{3. 結果および考察}

\section{1 板幅に及ぼすロール周速度およびスラリー供給量の 影響}

Table 2 の条件にもとづいて, スラリー供給量とロール周速 度から次の（1）式から計算により求めた板幅の值を Fig. 4 に示した。 


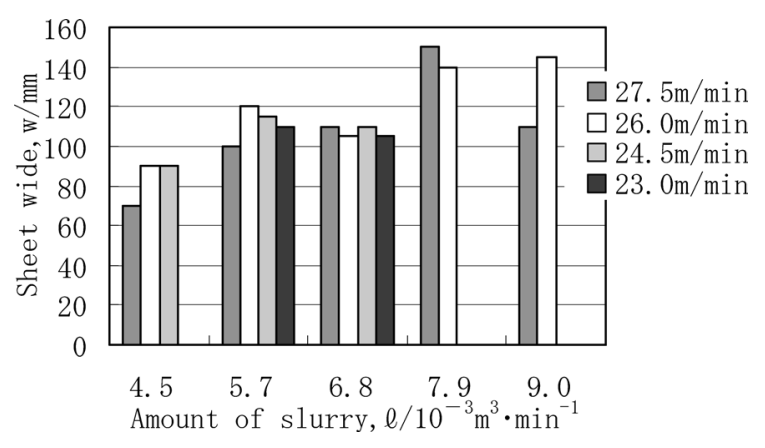

Fig. 5 Influence of amount of semisolid slurry on width of casting sheet. Portions without date indicate conditions which the casting sheet was not obtained.

$$
\begin{aligned}
\text { 板幅 }= & \left(\text { 制御棒降下速度 } \times(\text { 制御棒半径 })^{2} \times \pi\right) / \\
& (\text { 板厚 } \times \text { ロール周速度 })
\end{aligned}
$$

この結果から，スラリー供給量を増加させ，ロール周速度 を小さくすれば，板幅が増加することができると推定された。

これに対して, Fig. 5 は実験結果を示したものである。Fig. 4 とは異なり, 板幅は供給量とは一義的な変化をしないこと がわかる。ここで, ロール周速度が $27.5 \mathrm{~m} / \mathrm{min}$ の場合は, ス ラリ一供給量が $9.0 \times 10^{-3} \mathrm{~m}^{3} / \mathrm{min}$ のとき, 板幅は大きくならな かった。この理由は, スラリー供給量が多いにもかかわらず, ロール周速度が大きいために, 板幅が十分に広がる前にロー ルにより薄板が排出されたためと考えられる。また，スラ リー供給量 $7.9 \times 10^{-3} \mathrm{~m}^{3} / \mathrm{min}$ では双ロールに供給されるスラ リーの供給量が適切であり, ノズル内および双ロールでスラ リーが広がったため板幅が広がったと考えられる。

Fig. 5 に棒グラフのないスラリー供給量では, 薄板の連続 鋳造ができなかった。これは，タンディッシュが双ロールに 対して水平に設置されているため, スラリーの速度が一定に ならず，またスラリ一供給量 $4.5 \times 10^{-3} \mathrm{~m}^{3} / \mathrm{min}$ ではスラリーが 双ロールに供給される量に対してロール周速度が小さすぎる ためにスラリーがロールに接触している時間が長くなり, 双 ロールからの凝固界面がノズル側に移動するためと考えられ る。また，スラリー供給量 $7.9 \times 10^{-3} \mathrm{~m}^{3} / \mathrm{min}$ および $9.0 \times 10^{-3}$ $\mathrm{m}^{3} / \mathrm{min}$ ではロール周速度に対してスラリー供給量が多いた め, 双ロールから薄板が排出される前に双ロールにスラリー が過剰供給されて詰まってしまったためと考えられる。

\section{2 板幅に及ぼすタンディッシュ角度の影響}

Fig. 6 はロール周速度を $26.0 \mathrm{~m} / \mathrm{min}$, スラリー供給量を $6.8 \times 10^{-3} \mathrm{~m}^{3} / \mathrm{min}$ と一定にして, タンディッシュ設置角度を $5^{\circ}, 10^{\circ}, 15^{\circ}$ と変化させて連続鋳造実験を行った結果を示し たものである。なお， $0^{\circ}$ のデー夕は 3.1 節の值を引用した。 また，設置角度 -5 では，鋳造ができなかった。

Fig. 5 の結果から, タンディッシュ角度 $10^{\circ}$ の場合に 140 $\mathrm{mm}$ のあっとも広幅の薄板が得られた。これは双ロールに供 給されるスラリーの溶湯圧が適切な大きさであり, ノズル内 で広がったスラリーの幅と同様の板幅が得られたためと思わ れる。これに対して，50では設置角度が小さすぎて双ロール に供給されるスラリーの溶湯圧が小さく, 板幅が広がらず, 他方 $15^{\circ}$ では角度が大きいためにスラリーの溶湯圧が大きす ぎて，スラリーがノズル内で広がる前に双ロールに供給され， 薄板に鋳造されたためと思われる。

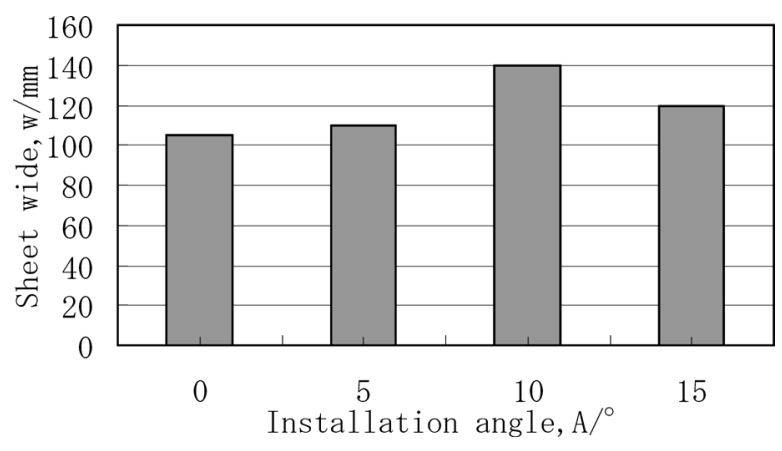

Fig. 6 Influence of the nozzle inclination angle to the lower roll on width of casting sheet.

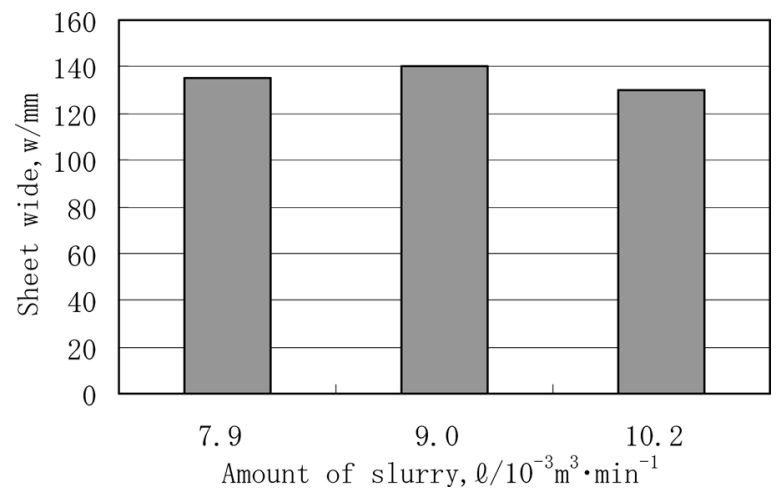

Fig. 7 Influence of amount of semisolid slurry on width of casting sheet. Nozzle inclination angle is fixed at 10 degrees.

\section{3 タンディッシュ角度 $10^{\circ}$ での板幅に及ぼすスラリー供 給量の影響}

3.2 節より得られた結果を踏まえて, あっと屯広幅の薄板 が得られたタンディシュ角度である $10^{\circ}$ を用いて，スラリー 供給量を増加させて板幅への影響を調べた。Fig. 7 はその結 果を示したものであるが，スラリ一供給量を増加させても板 幅を増加することはできなかった。この理由は, スラリ一供 給量を変化させることで, タンディシュの湯溜り部にスラ リーが溜まり, 溶湯圧が上昇し，それによりノズル内でスラ リーが広がると考えて実験を行ったが, タンディッシュ角度 $10^{\circ}$ ではスラリーがノズル内で広がらずにそのまま鋳造され たためと思われる。したがって, タンディシュ角度 $10^{\circ}$ では, 板幅 $140 \mathrm{~mm}$ が限界であることがわかった。

\section{4 タンディッシュ角度 $-5^{\circ}$ での板幅に及ぼすロール周 速度の影響}

Fig. 8 は夕ンディッシュ角度を $-5^{\circ}$ に固定して, ロール周 速度を変化させた場合の板幅に及ぼす影響を示したものであ る。これより, ロール周速度が小さい $21.5 \mathrm{~m} / \mathrm{min}$ の場合に本 研究では最大の板幅 $180 \mathrm{~mm}$ が得られた。したがって, スラ リーがこの角度でもっともノズル内で広がりやすく, かつ一 定速度でスラリーがロール間に供給され, スラリーの供給量 と双ロールからの薄板の排出量が一致していることがわかる。

Fig. 9 は得られた長さ約 $1 \mathrm{~m}$ の薄板表面の外観の一部であ る。板幅は長さ方向で測定場所により約 $10 \mathrm{~mm}$ のばらつきが あるが，ほぼ均一な板幅であると見なした。

Fig. 10 はこの連続鋳造薄板のミクロ組織である。微細な 初晶マグネシウムが板全体に均一に分散していることが認め 


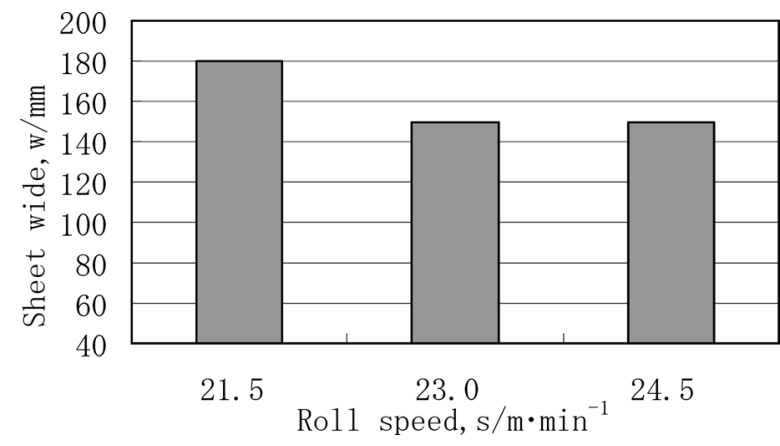

Fig. 8 Influence of roll speed on width of casting sheet. Nozzle inclination angle to lower roll is fixed at -5 degrees.

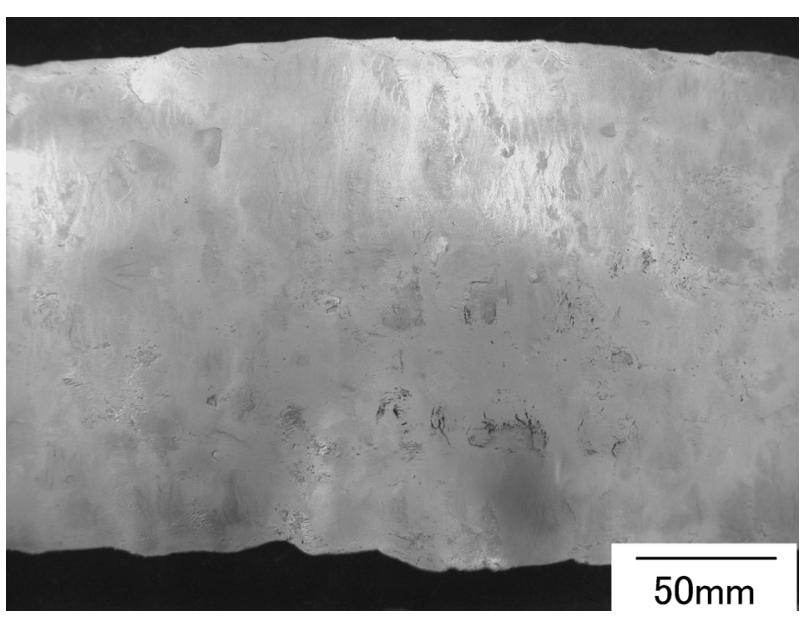

Fig. 9 Appearance of $180 \mathrm{~mm}$-wide sheet obtained by inclination angle of -5 degrees, roll speed of $21.5 \mathrm{~m} / \mathrm{min}$, and semisolid slurry volume of $10.2 \times 10^{-3} \mathrm{~m}^{3} / \mathrm{min}$.

られた。また, 各鋳造条件で得られたすべての連続鋳造薄板 のその表面状態およびミクロ組織は板幅方向および長手方向 にも差異は見られなかった。

得られた初晶マグネシウムの平均結晶粒径は $35 \mu \mathrm{m}$ であっ た。これは，傾斜冷却板上で生成遊離してタンディッシュに 入り，さらに双ロールに打いて鋳造凝固されるまでに結晶が 成長した大きさにそれほよ゙大きな違いがないことを示してい る。なお, 本研究で得られた異なった板幅に対する板厚の变

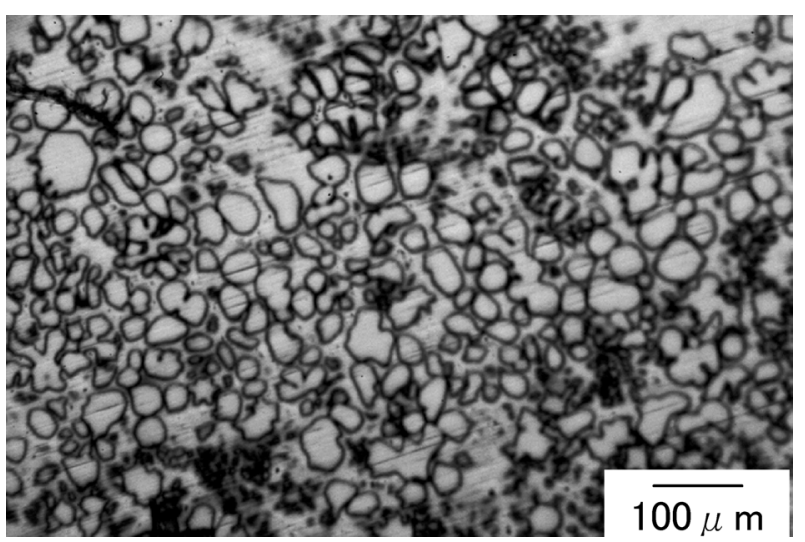

Fig. 10 Microstructure of casting sheet presented in Fig. 9.

動はすべて $2.0 \pm 0.3 \mathrm{~mm}$ 以内であった。

\section{4. 結言}

本研究は AZ31B マグネシウム合金の薄板を連続鋳造によ り作製するために，とくに板厚 $2 \mathrm{~mm}$ ，板幅 $180 \mathrm{~mm}$ の薄板を 作製するために，セミソリッドスラリーを双ロールにより鋳 造し，その際のスラリ一供給量，ロール周速度およびタン ディッシュ角度を変化させて実験を行った。その結果以下の ことが明らかとなった。

（1）スラリー供給量を増加すると板幅が大きくなる。

（2）タンディッシュ角度を変化させると，板幅が変化する。

（3）ロール周速度を小さくすると板幅が大きくなる。とく にタンディシュ角度が $-5^{\circ}$ では，板幅に大きく影響する。

（4）スラリ一供給量，ロール周速度およびタンディッシュ 角度は初晶の寸法形状に影響しない。

\section{参 考 文 献}

1）日本マグネシウム協会：マグネシウム技術便覧，カロス出版， (2000), 241.

2）茂木獄一：アルトピア， 3 (2005)，21-22.

3）城戸太司, 茂木徹一：日本金属学会誌，71 (2007), 758-762.

4）羽賀俊雄, 石原勝之, 片山 剛, 西山丈司：軽金属, 48 (1998), 613-617.

5）西田進一，本村 貢：軽金属，55 (2005)，315-316. 